\title{
PROBLEM OF FUZZY PORTFOLIO OPTIMIZATION AND ITS SOLUTION WITH APPLICATION OF FORECASTING METHODS
}

\author{
YURI ZAYCHENKO, INNA SYDORUK
}

\begin{abstract}
The novel theory of investment portfolio optimization under uncertainty is presented based on fuzzy set theory and efficient forecasting methods. The direct problem of fuzzy portfolio optimization and dual problem are considered. In the direct problem structure of a portfolio is determined which provides the maximum profitableness at the given risk level. In dual problem the portfolio structure is determined which provides the minimum risk level at the set level of critical profitableness. For estimation of stocks profitableness in future moment the application of forecasting method- Fuzzy Group Method of Data Handling (FGMDH) is suggested. This method enables to construct fuzzy forecasting models by experimental data almost automatically. The experimental investigations of the suggested theory were carried out and comparison with classical portfolio model was performed.
\end{abstract}

\section{INTRODUCTION}

Historically, the first and the most common way to take account of uncertainty is the use of probability theory. The beginning of modern investment theory was in the article H. Markowitz, "Portfolio Selection", which was released in 1952. In this article mathematical model of optimal portfolio of securities was first proposed. Methods of constructing such portfolios under certain conditions are based on theoretical and probabilistic formalization of the concept of profitability and risk. For many years the classical theory of Markowitz was the main theoretical tool for optimal investment portfolio construction, after which most of the novel theories were only modifications of the basic theory. However, the global market crisis of recent years has shown that the existing theory of investment portfolio optimization and forecasting stock indices exhausted itself and a revision of the basic theory of portfolio management is strongly needed.

New approach in the problem of investment portfolio construction under uncertainty is connected with fuzzy sets theory. Fuzzy sets theory was created about half a century ago in the fundamental work of Lotfi Zadeh [1]. By using fuzzy numbers in the forecast parameters decision- making person was not required to form probability estimates.

The application of fuzzy sets technique enabled to create a novel theory of fuzzy portfolio optimization under uncertainty and risk deprived of drawbacks of classical portfolio theory by Markovitz. 
The main source of uncertainty is changing stock prices of securities at the stock market as the decision on portfolio is based on current stock prices while the implementation of portfolio is performed in future and portfolio profitableness depends on future prices which are unknown at the moment of decision making. Therefore in order to raise the reliability of decision concerning portfolio and cut possible risk it' $s$ needed to forecast future prices of stocks. For this the application of inductive modeling method, so-called Fuzzy Froup Method of Data Handling (FGMDH) seems to be very perspective.

The goals of this work are to review the main results in fuzzy portfolio optimization theory, to consider and analyze so-called direct and dual problem of portfolio optimization, to estimate the application of FGMDH for stock prices forecasting and to carry out experimental investigations for estimation of the efficiency of the elaborated theory.

\section{PROBLEM STATEMENT}

Let us consider a share portfolio from $\mathrm{N}$ components and its expected behavior at time interval $[0, T]$. Each of a portfolio component $i=1, \ldots, N$ at the moment $T$ is characterized by it's financial profitableness $r_{i}$ (evaluated at a point $T$ as a relative increase in the price of the asset for this period) [2,3]. The holder of a share portfolio - the private investor, the investment company or mutual fund - operates the investments, being guided by certain reasons. On one hand, the investor tries to maximize the profitableness. On the other hand, he fixes maximum permissible risk of an inefficiency of the investments.

Assume the capital of the investor be equal 1. The problem of share portfolio optimization consists in a finding of a vector of share prices distribution in a portfolio $x=\left\{x_{i}\right\}, i=\overline{1, N}$ maximizing the income at the set risk level .

In process of practical application of Markovitz model its drawbacks were detected:

The hypothesis about normality of profitableness distributions in practice does not prove to be true.

Stationarity of price processes is not always confirmed in practice.

At last, the risk of stocks is considered as a dispersion i.e. a decrease in profitableness of securities in relation to the expected value, and profitableness increase in relation to an expected value are estimated in this model absolutely all the same. While for the proprietor of securities these events are absolutely different. These weaknesses of Markovitz theory determine necessity of essentially new approach of definition of an optimum investment portfolio.

\section{tion method.}

Let's review the main principles and ideas of a fuzzy portfolio optimiza-

The risk of a portfolio is not its volatility, but possibility that expected profitableness of a portfolio will appear below some pre-established planned value.

Correlation of stock prices in a portfolio is not considered and not accounted.

Profitableness of each security is not random but a fuzzy number. Similarly, restriction on extremely low level of profitableness can be both usual scalar and fuzzy number of any kind.

Profitableness of a security on termination of ownership term is expected to be equal $r$ and lies in a settlement range. 
For $i$-th security denote:

$\overline{r_{i}}$ - the expected profitableness of the $i$-th security;

$r_{1 i}$ - the lower border of profitableness of the $i$-th security;

$r_{2 i}$ - the upper border of profitableness of the $i$-th security.

$r_{i}=\left(r_{1 i}, \bar{r}_{i}, r_{2 i}\right)$ - profitableness of $i$-th security is a triangular fuzzy number.

Then profitableness of a portfolio:

$$
r=\left(r_{\min }=\sum_{i=1}^{N} x_{i} r_{1 i} ; \bar{r}=\sum_{i=1}^{N} x_{i} \bar{r}_{i} ; r_{\max }=\sum_{i=1}^{N} x_{i} r_{2 i}\right),
$$

where $x_{i}$ is the weight of the $i$-th security in a portfolio (its ratio), and

$$
\sum_{i=1}^{N} x_{i}=1, x_{i} \geq 0, \quad i=\overline{1, N} .
$$

Critical level of profitableness of a portfolio at the moment of $T$ may be fuzzy triangular number $r^{*}=\left(r_{1}^{*} ; r^{*} ; r_{2}^{*}\right)$ or non-fuzzy number.

To define structure of a portfolio which will provide the maximum profitableness at the set risk level, it is required to solve the following problem [6]:

$$
\left\{x_{\text {opt }}\right\}=\{x\} \mid r \rightarrow \max , \beta=\text { const },
$$

where $r$ is a portfolio profitableness, $\beta$ is a desired risk, vector $x$ satisfies (1).

\section{MATHEMATICAL MODEL OF FUZZY PORTFOLIO OPTIMIZATION PROBLEM}

Let us consider a risk estimation of portfolio investments. On fig. 1 membership function of $r$ and criterion value $r^{*}$ are shown.

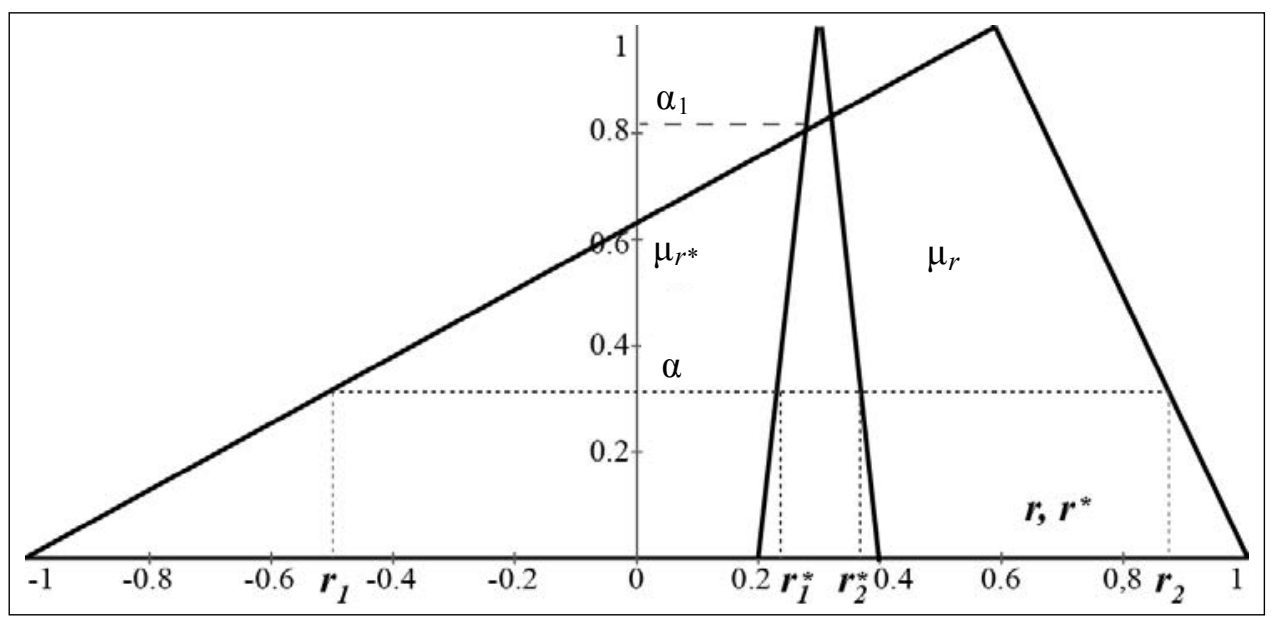

Fig. 1. Membership functions of $r$ and $r^{*}$

Point with ordinate $\alpha_{1}$ is the crossing point of two membership functions. Let us choose any level of membership $\alpha$ and define corresponding intervals 
$\left[r_{1}, r_{2}\right]$ and $\left[r_{1}^{*}, r_{2}^{*}\right]$. At $r_{1}>r_{2}^{*}$, intervals are not crossed, the risk and inefficiencies level equal to zero. Level $\alpha_{1}$ is upper border of risk zone. At $0 \leq \alpha \leq \alpha_{1}$ intervals are crossed.

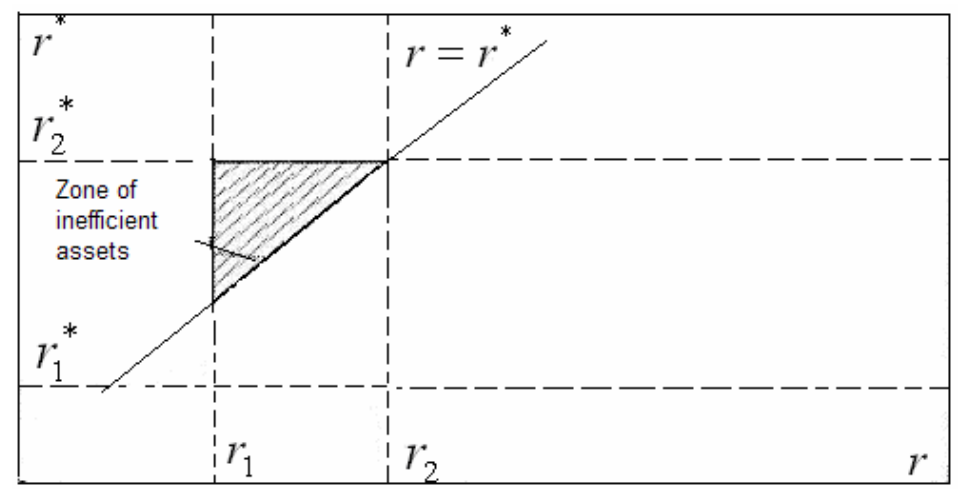

Fig. 2. Phase space $\left(r, r^{*}\right)$

$$
S_{\alpha}=\left\{\begin{array}{l}
0, \text { if } r_{1} \geq r_{2}^{*}, \\
\frac{\left(r_{2}^{*}-r_{1}\right)^{2}}{2}, \text { if } \mathrm{r}_{2}^{*}>r_{1} \geq r_{1}^{*}, r_{2} \geq r_{2}^{*}, \\
\frac{\left(r_{1}^{*}-r_{1}\right)+\left(r_{2}^{*}-r_{1}\right)}{2}\left(r_{2}^{*}-r_{1}^{*}\right), \text { if } r_{1}<r_{1}^{*}, r_{2}>r_{2}^{*}, \\
\left(r_{2}^{*}-r_{1}^{*}\right)\left(r_{2}-r_{1}\right)-\frac{\left(r_{2}-r_{1}^{*}\right)^{2}}{2}, \text { if } r_{1}<r_{1}^{*} \leq r_{2} ; r_{2}<r_{2}^{*}, \\
\left(r_{2}^{*}-r_{1}^{*}\right)\left(r_{2}-r_{1}\right), \text { if } r_{2} \geq r_{1}^{*},
\end{array}\right.
$$

where $S_{\alpha}$ are shaded areas of the phase space.

Since all realizations $\left(r, r^{*}\right)$ at set membership level $\varphi(\alpha)$ are equally possible, so the degree of inefficiencies risk $\varphi(\alpha)$ is geometrical probability of event to drop into any point $\left(r, r^{*}\right)$ in the zone of inefficient distribution of the capital [5]:

$$
\varphi(\alpha)=\frac{S_{\alpha}}{\left(r_{2}^{*}-r_{1}^{*}\right)\left(r_{2}-r_{1}\right)} .
$$

Then total value of risk level of portfolio inefficiency is equal to:

$$
\beta=\int_{0}^{\alpha_{1}} \varphi(\alpha) d \alpha .
$$

When the criterion of efficiency is defined as non-fuzzy level $r^{*}$ limiting transition at $r_{2}^{*} \rightarrow r_{1}^{*} \rightarrow r^{*}$ we obtain:

$$
\varphi(\alpha)=\left\{\begin{array}{l}
0, \text { if } r^{*}<r_{1}, \\
\frac{\left(r^{*}-r_{1}\right)}{\left(r_{2}-r_{1}\right)}, \text { if } r_{1} \leq r^{*} \leq r_{2}, \alpha \in[0,1], \\
1, \text { if } r^{*}>r_{2} .
\end{array}\right.
$$


The most expected value risk degree of a portfolio is defined so [2]:

$$
\beta=\left\{\begin{array}{l}
0, \text { if } r^{*}<r_{\min }, \\
R\left(1+\frac{1-\alpha_{1}}{\alpha_{1}} \ln \left(1-a_{1}\right)\right), \text { if } r_{\min } \leq r^{*} \leq \bar{r}, \\
1-(1-R)\left(1+\frac{1-\alpha_{1}}{\alpha_{1}} \ln \left(1-a_{1}\right)\right), \text { if } \bar{r} \leq r^{*}<r_{\max }, \\
1, \text { if } r^{*} \geq r_{\max },
\end{array}\right.
$$

where

$$
\begin{gathered}
R=\left\{\begin{array}{l}
\frac{r^{*}-r_{\min }}{r_{\max }-r_{\min }}, \text { if } r^{*}<r_{\max }, \\
1, \text { if } r^{*} \geq \mathrm{r}_{\max },
\end{array}\right. \\
\alpha_{1}= \begin{cases}0, & \text { if } r^{*}<r_{\min }, \\
\frac{r^{*}-r_{\min }}{\widetilde{r}-r_{\min }}, & \text { if } \quad r_{\min } \leq r^{*}<\widetilde{r}, \\
1, & \text { if } r^{*}=\widetilde{r}, \\
\frac{r_{\max }-r^{*}}{r_{\max }-\widetilde{r}}, & \text { if } \quad \widetilde{r}<r^{*}<r_{\max }, \\
0, & \text { if } \quad r^{*} \geq r_{\max } .\end{cases}
\end{gathered}
$$

Taking into account also that profitableness of a portfolio is equal to:

$$
r=\left(r_{\min }=\sum_{i=1}^{N} x_{i} r_{1 i} ; \bar{r}=\sum_{i=1}^{N} x_{i} \bar{r}_{i} ; r_{\max }=\sum_{i=1}^{N} x_{i} r_{2 i}\right),
$$

where $r_{i}=\left(r_{1 i}, \bar{r}_{i}, r_{2 i}\right)$ is the profitableness of $i$-th security, we obtain the following direct portfolio optimization problem [6]:

$$
\begin{gathered}
\bar{r}=\sum_{i=1}^{N} x_{i} \bar{r}_{i} \rightarrow \max , \\
\beta=\mathrm{const}, \\
\sum_{i=1}^{N} x_{i}=1, \quad x_{i} \geq 0, \quad i=\overline{1, N} .
\end{gathered}
$$

At a risk level variation $\beta 3$ cases are possible. Consider in detail each of them.

- $\beta=0$.

From (3) it is evident, that this case is possible when $r^{*}<\sum_{i=1}^{N} x_{i} r_{1 i}$. 
Then we receive the following problem of linear programming:

$$
\begin{gathered}
\bar{r}=\sum_{i=1}^{N} x_{i} \bar{r}_{i} \rightarrow \max , \\
\sum_{i=1}^{N} x_{i} r_{1 i}>r^{*}, \\
\sum_{i=1}^{N} x_{i}=1, \quad x_{i} \geq 0, \quad i=\overline{1, N} .
\end{gathered}
$$

The solution of the problem (9)-(11) - vector $x=\left\{x_{i}\right\}, i=\overline{1, N}$ determines a required structure of the optimum portfolio for the given risk level.

- $\beta=1$.

From (3) it follows, that this case is possible when $r^{*} \geq \sum_{i=1}^{N} x_{i} r_{2 i}$. Then we get the following problem

$$
\begin{gathered}
\bar{r}=\sum_{i=1}^{N} x_{i} \bar{r}_{i} \rightarrow \max \\
\sum_{i=1}^{N} x_{i} r_{2 i} \leq r^{*}, \quad \sum_{i=1}^{N} x_{i}=1, \quad x_{i} \geq 0, \quad i=\overline{1, N} .
\end{gathered}
$$

- $0<\beta<1$.

From (3) it is evident, that this case is possible when $\sum_{i=1}^{N} x_{i} r_{1 i} \leq r^{*} \leq$ $\leq \sum_{i=1}^{N} x_{i} \bar{r}_{i}$, or when $\sum_{i=1}^{N} x_{i} \bar{r}_{i} \leq r^{*}<\sum_{i=1}^{N} x_{i} r_{2 i}$.

a) Let be $\sum_{i=1}^{N} x_{i} r_{1 i} \leq r^{*} \leq \sum_{i=1}^{N} x_{i} \bar{r}_{i}$. Then using (4)-(5) the problem (6)-(8) is reduced to the following nonlinear programming problem :

$$
\begin{gathered}
\bar{r}=\sum_{i=1}^{N} x_{i} \bar{r}_{i} \rightarrow \max \\
\frac{1}{\sum_{i=1}^{N} x_{i} r_{2 i}-\sum_{i=1}^{N} x_{i} r_{1 i}}\left(\left(r^{*}-\sum_{i=1}^{N} x_{i} r_{1 i}\right)+\left(\sum_{i=1}^{N} x_{i} \bar{r}_{i}-r^{*}\right) \ln \left(\frac{\sum_{i=1}^{N} x_{i} \bar{r}_{i}-r^{*}}{\sum_{i=1}^{N} x_{i} \bar{r}_{i}-\sum_{i=1}^{N} x_{i} r_{1 i}}\right)\right)=\beta \\
\sum_{i=1}^{N} x_{i} r_{1 i} \leq r^{*} \\
\sum_{i=1}^{N} x_{i} \bar{r}_{i}>r^{*}
\end{gathered}
$$




$$
\sum_{i=1}^{N} x_{i}=1, \quad x_{i} \geq 0, \quad i=\overline{1, N}
$$

b) Let $\sum_{i=1}^{N} x_{i} \bar{r}_{i} \leq r^{*}<\sum_{i=1}^{N} x_{i} r_{2 i}$. Then the problem (6)-(8) is reduced to the following nonlinear programming problem:

$$
\begin{gathered}
\bar{r}=\sum_{i=1}^{N} x_{i} \bar{r}_{i} \rightarrow \max , \\
\frac{1}{\sum_{i=1}^{N} x_{i} r_{2 i}-\sum_{i=1}^{N} x_{i} r_{1 i}} \times \\
\left.\times\left(r^{*}-\sum_{i=1}^{N} x_{i} r_{1 i}\right)-\left(r^{*}-\sum_{i=1}^{N} x_{i} \bar{r}_{i}\right) \ln \left(\frac{r^{*}-\sum_{i=1}^{N} x_{i} \bar{r}_{i}}{\sum_{i=1}^{N} x_{i} r_{2 i}-\sum_{i=1}^{N} x_{i} r_{1 i}}\right)\right)=\beta, \\
\sum_{i=1}^{N} x_{i} r_{2 i}>r^{*}, \\
\sum_{i=1}^{N} x_{i} \tilde{r}_{i} \leq r^{*}, \\
\sum_{i=1}^{N} x_{i}=1, x_{i} \geq 0, \quad i=\overline{1, N} .
\end{gathered}
$$

The R-algorithm of minimization of not differentiated functions was suggested to find the solution of problems (12)-(16) and (17)-(21).

Let both problems: (12)-(16) and (20)-(24) be solvable. Then to the structure of a required optimum portfolio will correspond such vector $x=\left\{x_{i}\right\}$, $i=\overline{1, N}$ - the solution one of the problems (12)-(16), (17)-(21) whose the criterion function value will be greater.

\section{ANALYSIS AND COMPARISON OF EXPERIMENTAL RESULTS OBTAINED BY MARKOVITZ AND FUZZY PORTFOLIO MODELS}

For the comparative analysis of investigated methods of a share portfolio optimization real data on share prices of the companies RAO» EES (EERS2) and Gazprom (GASP), were taken from February, 2000 till May, 2006 [6, 7].

In Markovitz model expected profitableness of a share is calculated as a mean $m=M\{r\}$ and risk of an asset is considered as a dispersion of the profitableness value $\sigma^{2}=M\left[(m-r)^{2}\right]$ i.e. level of variability of expected incomes.

In the fuzzy-sets model obtained from a situation at the share market we conclude: 
- the profitableness of EERS2 shares lies in a settlement corridor $[-1,0: 3,9]$, the most expected value of profitableness is $2,1 \%$;

- the profitableness of GASP shares lies in a settlement corridor [-4,1: 5,7], the most expected value of profitableness is $4,8 \%$.

Let critical profitableness of a portfolio be $3,5 \%$ i.e. portfolio investments which bring the income below $3,5 \%$, are considered as the inefficient.

Expected profitableness of the optimum portfolios received by Markovitz model, is higher, than profitableness of optimum portfolios, received by the fuzzy-set model because in Markovitz model the calculation of expected share profitableness is based on indicators for the preceeding periods and the situation in the share market at the moment of decision-making is not accountedby the investor. As profitableness of shares EERS2 and GASP in 2000- 2005 years was much more higher than at the present moment, Markovitz model gives unfairly high estimate.

In the fuzzy-set model the profitableness of each asset is a fuzzy number. Its expected value is calculated not from statistical data, but by analysis of the market at the moment of decision- making by the investor. Thus, in the considered case, the expected profitableness of a portfolio is not too high.

The structures of an optimum portfolio which we get as a result of use of both methods for the same risk levels are quite different too. To find out the reason of this we consider following dependences obtained for both models (Fig. 3) Dependence of expected profitableness on risk degree of the portfolio is presented in Fig. 3.
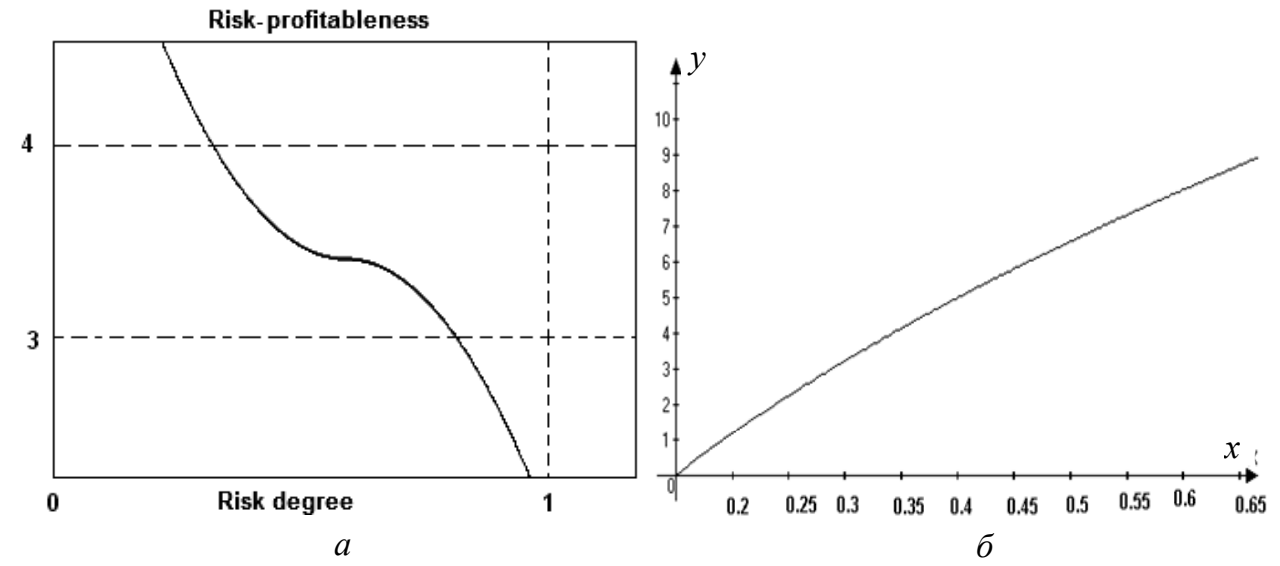

Fig. 3. Dependences of expected profitableness on degree of risk of the portfolio: $a-$ Fuzzy portfolio model; $b$ - Markovitz model

The dependencies "optimal profitableness-risk" received by the above specified methods, are practically opposite. The reason of such result is the various understanding of a portfolio risk.

In the fuzzy-set method the risk is recognized as a situation when expected profitableness of a portfolio falls below the critical level, so with decrease of expected profitableness, risk of the real portfolio profitableness to be less thanthe critical value, increases .

In Markovitz model the risk is considered as the degree of expected income variability of a portfolio, in both cases of smaller and greater income that contra- 
dicts common sense. The various understanding of portfolio risk level is also the reason of difference of a portfolio structure, received by different methods.

From the point of view of the fuzzy-set approach, the greater is the portion of GASP shares in a portfolio, the less is the risk of that efficiency of share investments will appear below the critical level which is in our case 3,5\%.

From the point of view of Markovitz model, average mean deviation from average value for GASP shares is great enough, therefore with growth of this share portion the risk of a portfolio increases. It leads to that portion of highly profitable assets in the share portfolio received by Markovitz model, is unfairly small.

According to Markovitz model, thanks to correlation between assets it is possible to receive a portfolio with a risk level less than volatility of the least risk security.

In this research after investing $96 \%$ of the capital in EERS2 shares and $4 \%$ in GASP shares, the investor received portfolio with expected profitableness of $2,4 \%$ and degree of risk 0,19 . However investments with expected profitableness of $2,4 \%$ in our fuzzy-set model are considered as the inefficient. If to set critical value of expected portfolio profitableness equal to $2,4 \%$ the risk of inefficient investments will decrease, too.

\section{DUAL PORTFOLIO OPTIMIZATION PROBLEM}

Now consider the portfolio optimization problem dual to the problem (6)-(8) $[2,10]$ :

under conditions

$$
\min \beta(x)
$$

$$
\begin{gathered}
\bar{r}=\sum_{i=1}^{N} x_{i} \bar{r}_{i} \geq r_{\text {set }}=r^{*}, \\
\sum_{i=1}^{N} x_{i}=1, \quad x_{i} \geq 0, \quad i=\overline{1, N} .
\end{gathered}
$$

In the paper [3], it was proved that the risk function $\beta(x)$ is convex where

$$
\beta(x)=\left(A(x)+B(x) \ln \frac{B(x)}{C(x)}\right) D(x),
$$

where

$$
\begin{gathered}
A(x)=r^{*}-\sum_{i=1}^{N} x_{i} r_{1 i} ; \quad B(x)=\sum_{i=1}^{N} x_{i} \bar{r}_{i}-r^{*} ; \\
C(x)=\sum_{i=1}^{N} x_{i} \bar{r}_{i}-\sum_{i=1}^{N} x_{i} r_{1 i} .
\end{gathered}
$$

So the dual portfolio problem (22)-(24) is convex programming problem. Taking into account that constraints (23) are linear compose Lagrangian function: 


$$
\left.L(x, \lambda, \mu)=\beta(x)+\lambda\left(r^{*}-\sum_{i=1}^{N} x_{i} \bar{r}_{i}\right)+\mu\left(\sum_{i=1}^{N} x_{i}-1\right)\right) .
$$

The optimality conditions by Kuhn-Tucker are such [3]:

$$
\begin{gathered}
\frac{\partial L}{\partial x_{i}}=\frac{\partial \beta(x)}{\partial x_{i}}-\lambda \bar{r}_{i}+\mu \geq 0, \quad i=\overline{1, N}, \\
\frac{\partial L}{\partial \lambda}=-\sum_{i=1}^{N} x_{i} \bar{r}_{i}+r^{*} \leq 0, \\
\frac{\partial L}{\partial \mu}=\sum_{i=1}^{N} x_{i}-1=0,
\end{gathered}
$$

and conditions of complementary slackness

$$
\frac{\partial L}{\partial x_{i}} x_{i}=0, \frac{\partial L}{\partial \lambda}=\lambda\left(-\sum_{i=1}^{N} x_{i} \bar{r}_{i}+r^{*}\right)=0, \quad x_{i}, \lambda \geq 0, \quad i=\overline{1, N},
$$

where $\lambda \geq 0$ and $\mu$ are indefinite Lagrange multipliers.

This problem may be solved by standard methods of convex programming, for example method of feasible directions or method of penalty functions.

\section{THE APPLICATION OF FGMDH FOR STOCK PRICES FORECASTING AND EXPERIMENTAL INVESTIGATIONS}

The profitableness of leading companies at NYSE in the period from 03.09.2013 to 17.01.2014 were used as the input data in experimental investigations. The companies included: Canon Inc. (CAJ), McDonald's Corporation (MCD), PepsiCo, Inc (PEP), The Procter \& Gamble Company (PG), SAP AG (SAP).

For forecasting we have used Fuzzy GMDH method [5, 2] with triangular

\begin{tabular}{|c|c|c|c|c|c|c|}
\hline \multirow[b]{2}{*}{ Companies } & \multicolumn{4}{|c|}{ Profitableness } & \multirow{2}{*}{$\begin{array}{c}\text { MAPE } \\
\text { test } \\
\text { sample }\end{array}$} & \multirow{2}{*}{$\begin{array}{c}\text { MSE } \\
\text { test } \\
\text { sample }\end{array}$} \\
\hline & Real value & Low bound & $\begin{array}{c}\text { Forecasted } \\
\text { value }\end{array}$ & $\begin{array}{l}\text { Upper } \\
\text { bound }\end{array}$ & & \\
\hline CAJ & $-1,270$ & $-1,484$ & $-1,246$ & $-1,008$ & 2,2068 & 0,0295 \\
\hline MCD & $-0,105$ & $-0,347$ & $-0,118$ & 0,111 & 2,5943 & 0,0091 \\
\hline PEP & 0,206 & 0,001 & 0,242 & 0,483 & 3,0179 & 0,0177 \\
\hline PG & 0,162 & 0,041 & 0,170 & 0,299 & 1,6251 & 0,0197 \\
\hline SAP & 0,843 & 0,675 & 0,867 & 1,059 & 2,3065 & 0,0164 \\
\hline
\end{tabular}
membership functions, linear partial descriptions, training sample of 70 and forecasting for 1 step. The next profitableness values on date 17.01.2014 were obtained (table 1).

Table 1. The profitableness of shares on date 17.01.2014, \%

Let the critical profitableness level be $0,7 \%$. Varying the risk level we obtain the following results at the end of 2-nd week (17.01.2014) for triangular MF. The results are presented in the tables 2, 3 and the Fig. 4. 
Table 2. Distribution of components of the optimal portfolio for triangular MF with critical level $r^{*}=0,7 \%$

\begin{tabular}{|c|c|c|c|c|}
\hline CAJ & MCD & PEP & PG & SAP \\
\hline $\mathbf{0 , 0 5 4 8 2}$ & $\mathbf{0 , 0 0 1 9 6}$ & $\mathbf{0 , 0 0 2 7}$ & $\mathbf{0 , 0 0 2 3 4}$ & $\mathbf{0 , 9 3 8 1 8}$ \\
\hline 0,06145 & 0,00113 & 0,00606 & 0,0039 & 0,92746 \\
\hline 0,0698 & 0,00577 & 0,00235 & 0,00219 & 0,91989 \\
\hline 0,06871 & 0,00228 & 0,0057 & 0,00244 & 0,92087 \\
\hline 0,07567 & 0,00569 & 0,00106 & 0,00094 & 0,91664 \\
\hline 0,07553 & 0,00002 & 0,0029 & 0,00208 & 0,91947 \\
\hline 0,06774 & 0,00121 & 0,006 & 0,00234 & 0,92271 \\
\hline 0,0764 & 0,001 & 0,00612 & 0,00464 & 0,91184 \\
\hline 0,09072 & 0,00849 & 0,00655 & 0,0039 & 0,89034 \\
\hline
\end{tabular}

Table 3. Parameters of the optimal portfolio for triangular MF with critical level $r^{*}=0,7 \%$

\begin{tabular}{|c|c|c|c|}
\hline Low bound & $\begin{array}{c}\text { Expected } \\
\text { profitableness }\end{array}$ & Upper bound & Risk level \\
\hline 0,55133 & $\mathbf{0 , 7 4 5 9 1}$ & 0,94049 & $\mathbf{0 , 2}$ \\
\hline 0,53462 & 0,72954 & 0,92446 & 0,25 \\
\hline 0,51544 & 0,71084 & 0,90624 & 0,3 \\
\hline 0,51894 & 0,71431 & 0,90968 & 0,35 \\
\hline 0,5045 & 0,70018 & 0,89587 & 0,4 \\
\hline 0,50877 & 0,70425 & 0,89973 & 0,45 \\
\hline 0,522 & 0,71731 & 0,91262 & 0,5 \\
\hline 0,50197 & 0,69752 & 0,89308 & 0,55 \\
\hline 0,46358 & 0,66014 & 0,8567 & 0,6 \\
\hline
\end{tabular}

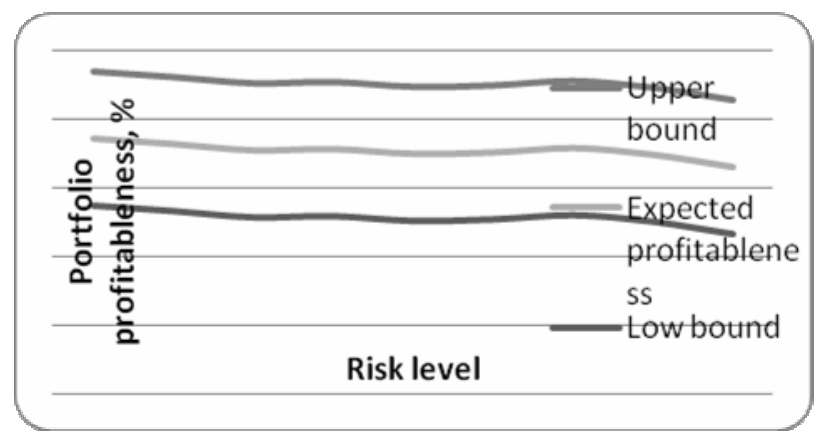

Fig. 4. Dependence of the expected portfolio profitableness versus risk level for triangular MF

As we can see on fig. 4, the dependence profitableness - risk has descending type, the greater risk the lesser is profitableness which is opposite to classical probabilistic method by Markovitz. It may be explained so that at fuzzy approach by risk is meant the situation when the expected profitableness happens to be less than the given criteria level. When the expected profitableness decreases, the risk grows. 
The profitableness of the real portfolio is $0,7056 \%$. This value falls in calculated corridor of profitableness for optimal portfolio [0,5346, 0,7295, 0,9245] built with application of forecasting method FGMDH, indicating the high accuracy of the forecast.

Now consider the same portfolio using Gaussian MF (table 4, fig. 5).

Table 4. Parameters of the optimal portfolio for Gaussian MF with critical level $r^{*}=0,7 \%$

\begin{tabular}{|c|c|c|c|}
\hline Low bound & $\begin{array}{c}\text { Expected } \\
\text { profitableness }\end{array}$ & Upper bound & Risk level \\
\hline 0,6833 & $\mathbf{0 , 8 7 5 5 1}$ & 1,06772 & $\mathbf{0 , 2}$ \\
\hline 0,66972 & 0,86178 & 1,05384 & 0,25 \\
\hline 0,66955 & 0,86161 & 1,05368 & 0,3 \\
\hline 0,66468 & 0,85682 & 1,04896 & 0,35 \\
\hline 0,64944 & 0,8415 & 1,03356 & 0,4 \\
\hline 0,65975 & 0,85185 & 1,04394 & 0,45 \\
\hline 0,63439 & 0,8266 & 1,0188 & 0,5 \\
\hline 0,63184 & 0,82389 & 1,01594 & 0,55 \\
\hline 0,62452 & 0,81666 & 1,0088 & 0,6 \\
\hline
\end{tabular}

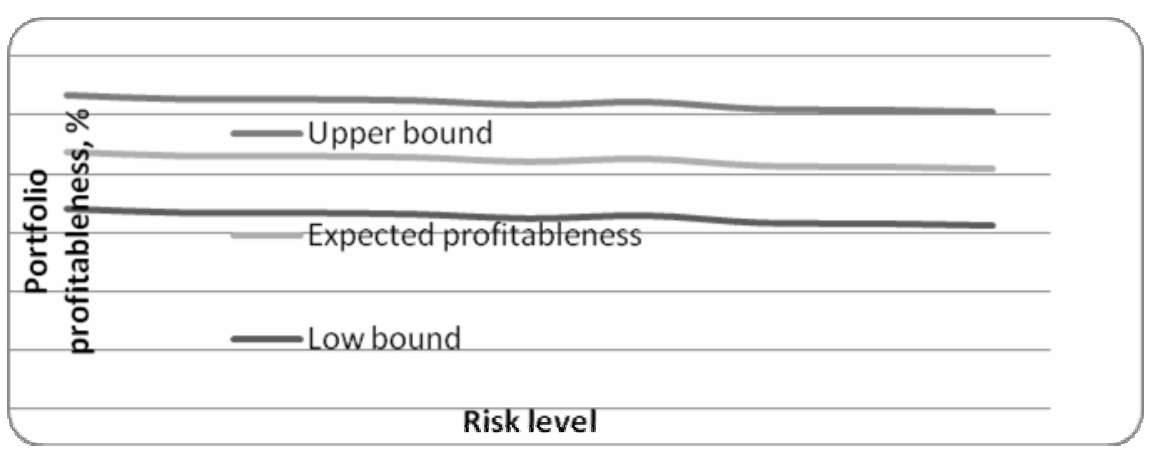

Fig. 5. Dependence of expected portfolio profitableness versus risk for Gaussian MF

The profitableness of the real portfolio is $0,8316 \%$. This value falls in calculated corridor of profitableness for optimal portfolio [0,6833; 0,8756; 1,0677].

In the above results the optimal portfolio corresponds to the first row of tables. As it can be seen from these data, the profitableness obtained using Gaussian and bell-shaped MF is higher than the profitableness obtained using triangular MF.

The optimal portfolio obtained with different MF actually have the same structure, the main portion falls on the company SAP shares, due to high rates of return as compared with other companies.

Let's consider the results obtained by solving the dual problem using triangular MF. In this case, the investor sets the rate of return, and the problem is to minimize the risk.

The optimal portfolio is presented in tables 5, 6 and Fig. 6 . 
Table 5. Distribution of components of the optimal portfolio (dual task)

\begin{tabular}{|c|c|c|c|c|}
\hline CAJ & MCD & PEP & PG & SAP \\
\hline 0,01627 & 0,02083 & 0,02226 & 0,02231 & 0,91833 \\
\hline 0,01112 & 0,02085 & 0,02391 & 0,02383 & 0,92029 \\
\hline 0,00333 & 0,01992 & 0,02517 & 0,02476 & 0,92682 \\
\hline 0,0021 & 0,01579 & 0,02457 & 0,02344 & 0,9341 \\
\hline 0,00004 & 0,00921 & 0,02423 & 0,02135 & 0,94517 \\
\hline 0,00224 & 0,00144 & 0,01825 & 0,01095 & 0,96712 \\
\hline 0,00044 & 0,00682 & 0,02508 & 0,02058 & 0,94708 \\
\hline 0,0011 & 0,00917 & 0,02448 & 0,02039 & 0,94486 \\
\hline 0,00294 & 0,01206 & 0,02533 & 0,02154 & 0,93813 \\
\hline
\end{tabular}

Table 6. Parameters of the optimal portfolio (dual task)

\begin{tabular}{|c|c|c|c|c|}
\hline Low bound & $\begin{array}{c}\text { Expected } \\
\text { profitableness }\end{array}$ & Upper bound & Risk level & $\begin{array}{c}\text { Critical rate } \\
\text { of return }\end{array}$ \\
\hline 0,58944 & 0,78264 & 0,97584 & 0,00025 & 0,6 \\
\hline 0,59846 & 0,79141 & 0,98437 & 0,01468 & 0,65 \\
\hline 0,61478 & 0,80735 & 0,99991 & 0,04973 & 0,7 \\
\hline 0,6229 & 0,81531 & 1,00772 & 0,13347 & 0,75 \\
\hline 0,63606 & 0,82822 & 1,02037 & 0,26399 & 0,8 \\
\hline 0,64945 & 0,84181 & 1,03417 & 0,49937 & 0,85 \\
\hline 0,63712 & 0,82933 & 1,02153 & 0,72631 & 0,86 \\
\hline 0,63382 & 0,82612 & 1,01843 & 0,8333 & 0,87 \\
\hline 0,62559 & 0,81805 & 1,01052 & 0,91214 & 0,88 \\
\hline
\end{tabular}

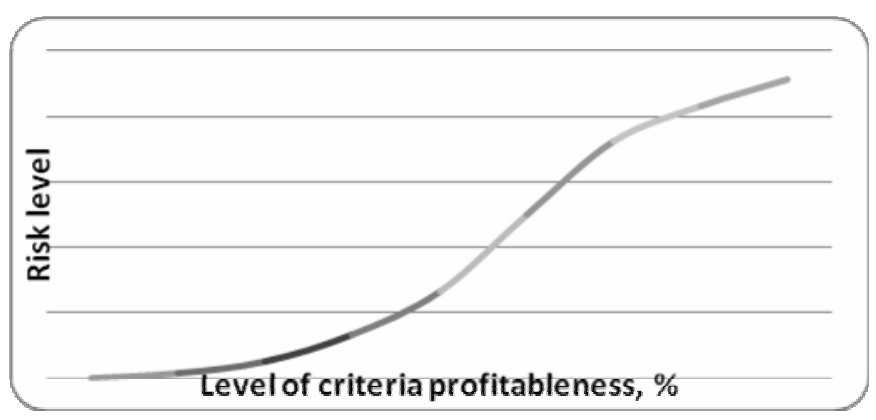

Fig. 6. Dependence of the risk level on a given critical return

From these results one can readily see that the curve "dependence risk given critical level of profitability" has a ascending character, because with the growth of the critical value of profitability increases the probability that the expected return would be lower than a given critical value.

\section{CONCLUSION}

1. The problem of optimization of the investment portfolio under uncertainty is considered in this paper. We suggested and explored the fuzzy-set approach for solving the direct and dual portfolio optimization problems. In the direct problem we used triangular, bell-shaped and Gaussian membership functions. The results of solving the tasks were presented. 
2. The optimal portfolios for the five assets at NYSE stock market were constructed and analyzed.

3. The problem of stock prices forecasting for portfolio optimization was also investigated. The fuzzy GMDH was proposed for its solution.. The fuzzy GMDH allows to construct forecasting model using experimental data automatically without participation of an expert. Besides, it may work under uncertainty conditions with fuzzy input data or data given as intervals. The fuzzy GMDH was applied for stocks profitableness forecasting at NYSE stock market in the problem of fuzzy portfolio optimization. The application of fuzzy GMDH enabled to decrease risk of the wrong decisions and to raise the groundness of decisions concerning portfolio content.

4. After analysis of the direct problem experiments it was detected that the dependence "profitableness - risk" has descending type, the greater risk the lesser is profitableness that is opposite to classical probabilistic methods.

5. The dependence "risk versus given critical level of profitability" has ascending type, because as the value of the critical level of profitability increases the probability that the expected return appears to be lower than a given critical value also grows.

6. As the main result of this research the theory of fuzzy portfolio optimization under uncertainty was developed based on fuzzy set approach and forecasting method FGMDH.

\section{REFERENCES}

1. Zadeh L.A. Fuzzy sets as a basis for a theory of possibility [Електронний pecypc] / L.A. Zadeh - Режим доступу: http://portal.acm.org/ citation. cfm?id=310820

2. Зайченко Ю.П. Нечеткие модели и методы в интеллектуальных системах [Текст]: учеб. пособие для студ. высш. учеб. заведений / Ю.П. Зайченко. К.: Слово, 2008. - 341c.

3. Згуровский М.,3, Основы вычислительного интеллекта / М.З. Згуровский, Ю.П. Зайченко. - М.: Наук. думка, 2013. — 406 с.

4. Недосекин А.О. Нечетко-множественный анализ риска фондовых инвестиций [Электронный pecypc] / А.О. Недосекин. - Режим доступа: logicbratsk.ru/radio/fuzzy/nedosek/book23.pdf

5. Зайченко Ю.П. Нечіткий метод групового врахування аргументів та його застосування в задачах прогнозування макроекономічних показників[Текст] / Ю.П. Зайченко, О.Г. Кебкал, В.Ф. Крачковський// Наукові вісті НТУУ «КПІ». - 2000. - № 2. - С. 18-26.

6. Зайченко Ю.П. Анализ и сравнение результатов оптимизации инвестиционного портфеля при применении модели Марковица и нечетко-множественного метода // XIII-th International Conference KDS-2007. — SOFIA, 2007.Vol. 1.-P.278-286.

7. Зайченко Ю.П. Оптимизация инвестиционного портфеля в условиях неопределенности // Системні дослідження та інформаційні технології. — 2008. № $2 .-$ C. $59-76$.

8. Зайченко Ю.П. Анализ инвестиционного портфеля на основе прогнозирования курсов акций // Інформатика, управління та обчислювальна техніка: Вісн. нац. техн. ун-ту України «КПІ». — К.: ТОО «ВЕК+». — 2007. — № 47. — С. 168-179.

9. Зайченко Ю. Исследование двойственной задачи оптимизации инвестиционного портфеля в нечетких условиях. Natural and Artificial Intelligence. ITHEA. Sofia, Bulgaria . - 2010. - P. 115-128.

10. Zaychenko $Y$. Direct and dual problem of investment portfolio optimization under uncertainty // International Journal «Information Technologies \& Knowledge». -8, N 3. - 2014. - P. 225-242.

Received 12.11.2015 